\title{
148. Magencarcinom und Serumelektrophorese
}

\author{
A. Tuchmann, J. Euler-Rolle und A. Priesching \\ 1. Chirurgische Universitätsklinik Wien
}

\section{Carcinoma of the Stomach and Serum Electrophoresis}

Summary. Typical findings in carcinoma of the stomach (350 patients) are correlated with fractions of protein electrophoreiis. Lower albumin and higher $\alpha$-globulin levels were found in the following situations: Advanced age, loss of weight, advancing penetration, metastasis of peritoneum and liver. Significantly higher $\beta$-globulin levels are found in ulcer carcinoma and lowered $\beta$-globulin in lymphnode metastasis. With a larger-diameter tumor only $\alpha_{1}$-globulin is elevated, and not $\alpha_{2}$-globulin. $\gamma$-globulin show divergent findings. The prognostic significance of protein fractions in carcinoma of the stomach is evident.

Key words: Carcinoma - Stomach - Electrophoresis, serum.

Zusammenfassung. Es werden Merkmale des Magencarcinoms mit den Elektrophoresewerten von 350 Patienten korreliert. Bei folgenden Kriterien sind die Albumine vermindert, die $\alpha$-Globuline vermehrt: Höheres Alter, größerer Gewichtsverlust, zunehmende Penetration, Fernmetastasen (gegenüber Metastasenfreiheit). Hohe $\beta$-Globuline finden sich beim Ulcuscarcinom und niedrige bei Lymphknotenmetastasen. Mit größerem Tumordurchmesser steigt nur das $\alpha_{2}$-Globulin, nicht das $\alpha_{1}$-Globulin. $\gamma$-Globuline zeigen ein divergierendes Verhalten. Auf die prognostische Bedeutung der Proteinfraktionen beim Magencarcinom wird hingewiesen.

Schlüsselwörter: Magencarcinom - Serumelektrophorese.

\section{Die Behandlung postoperativer gastrointestinaler Fisteln: Relaparotomie oder Hyperalimentation}

\author{
W. Peitsch und K. Burkhardt \\ Klinik und Poliklinik für Allgemeinchirurgie der Universität Göttingen
}

\section{Treatment of Postoperative Gastrointestinal Fistula: Relaparotomy or Hyperalimentation}

\begin{abstract}
Summary. Closure by relaparotomy was possible in only 37 of 65 patients with anastomotic insufficiency, and the lethality was 48.3 percent. During the same period, 29 cases of anastomotic leakage were treated by parenteral long-term hyperalimentation: spontaneous closure occurred in 20 . Duration of the infusion varied from 7 to 68 days, with a mean of 28.3 days. Certain fistulas of the lower small bowel show a special tendency for spontaneous closure. All anastomotic insufficiencies that are well drained should be treated primarily by parenteral hyperalimentation.
\end{abstract}

Key words: Fistula, gastrointestinal - Relaparotomy - Hyperalimentation. 